\title{
Perpetuities Revision in California: Perpetual Trusts Permitted
}

\author{
Jesse Dukeminier, Jr.*
}

TN 1963 the CALIFORNIA LEgislature revised the state's perpetuities 1 law. ${ }^{1}$ In a vivid description of this action, Dean Richard Maxwell has said the legislature "used an atomic cannon to kill a gnat." The gnat was Haggerty v. City of Oakland, ${ }^{2}$ a district court of appeals decision which held that a lease to commence upon completion of a building violated the Rule Against Perpetuities. The decision stunned many members of the California Bar. A special committee was named by the California Bar Association to draft legislation making appropriate changes in the Rule. This legislation was enacted in 1963.

One of the revisions, the new alternative definition of vesting, has received very little attention in the law reviews. Yet it is so drastic and sweeping as to make it possible in California to set up a private trust that can continue indefinitely and avoid estate and gift taxes throughout its existence. The revision raises an intriguing question of perpetuities policy: Does a private trust of indefinite duration, whicl can, after lives in being plus twenty-one years, be terminated by the beneficiaries, the Attorney General, or some other interested party, violate the policy against perpetuities? The revision also raises the possibility of the intervention of the Commissioner of Internal Revenue and the Congress in the perpetuities field. They cannot be expected to view with disinterest the possibilities of tax avoidance now available in California.

I

THE NEW ALTERNATIVE DEFINITION OF VESTING IN CAIIFORNIA:

THE ESSENCE OF CIVIL CODE SECTION $715.8^{3}$

In 1963 the California Civil Code was amended to provide in section 715.8:

*A.B., 1948, Harvard University; LL. B., 1951, Yale University. Professor of Law, University of California, Los Angeles.

1 The legislature provided for reformation of invalid interests by the exercise of a judicial cy pres power, CAI. CIv. CODE $§ 715.5$ (West Supp. 1966), provided an alternative 60-year period for vesting, CAI. Crv. Code $\$ 715.6$ (West Supp. 1966), abolished the unborn widow, CAL. CIv. CODE $\$ 715.7$ (West Supp. 1966), and provided an alternative definition of "vested," Car. Crv. Code $₹ 715.8$ (West Supp. 1966). Only the last of these revisions is discussed in this article.

For a compendious treatment of California perpetuities law, see Halbach, The Rulc Against Perpetuities, in CaLIFORNIA WIIL Draftang \$\$ 15.01-15.72 (1965).

2161 Cal. App. 2d 407, 326 P.2d 957 (1958). Shortly after the 1963 statutory revision the supreme court in Wong v. Di Grazia, 60 Cal. 2d 525, 386 P.2d 817, 35 Cal. Rptr. 241 (1963), refused to follow Haggerty and the gnat was thereby slain. 
An interest in real or personal property, legal or equitable, is vested if and when there is a person in being who could convey or there are persons in being, irrespective of the nature of their respective interests, who together could convey a fee simple title thereto. ${ }^{4}$

It is important first to note that this statute does not reinstate the rule repealed in 1959 forbidding the suspension of the power of alienation. This can be clearly seen by the following examples:

${ }^{3} \mathrm{~A}$ useful examination of the statute, including the constitutional question, can be found in Comment, The Quest for the Best Vest, 37 S. CaL. L. Rev. 283 (1964).

4 CAI. Crv. Code $\S 715.8$ (West Supp. 1966). The alternative definition of "vested" in \& 715.8 should be used only in solving perpetuities problems even though it is the only section numbered 715 whcih is not made expressly applicable to the Rule Against Perpetuities alone.

In California it appears that the classification of an interest as vested rather than contingent will not affect the result in any case unless it is claimed that the interest violates the Rule. All the old common law problems turning upon a vested or contingent classification have been abolished or rephrased to avoid such an artificial solution. (1) The doctrine of destructibility of contingent remainders has been abolished in Califormia. CAI. CTv. CODE $\$ \S 741-42$ (West 1954). (2) All interests in property are fully ahenable, devisable, and descendible in California. Estate of Ferry, 55 Cal. 2d 776, 361 P.2d 900, 13 Cal. Rptr. 180 (1961); Car. Crv. Code $\S 699$ (West 1954). (3) There is said to be a common law rule that vested remainders accelerate while contingent remainders do not. But cf. L. Smars \& A. SAItr, THE LAw of Future Interests $\S 796$ (2d ed. 1956). In Cahfornia, bowever, it has been held that Civil Code $\$ 780$ prevents acceleration of all remainders. Estate of Lefranc, 38 Cal. 2d 289, 239 P.2d 617 (1952); Estate of Arnis 186 Cal. 554, 199 P. 1053 (1921) (indefeasibly vested remainder). (4) In cases of incomplete dispositions of income, Cahifornia courts will most likely follow the New York courts in disposing of income to "the persons presumptively entitled to the next eventual interest," CAL. CIv. CODE $§ 733$ (West 1954), without drawing a distinction between vested and contingent interests. The New York courts, applying N.Y. ReAT Prop. LAw \& 63 (1945), from which the seldombitigated California statute relating to undisposed income is derived, have drawn no distinction between vested and contingent interests and have ordered undisposed income paid to the owners of the next succeeding interest unless such owners are not in being or not ascertained. 6 AMrerican LAW of Property $\$ 25.111$ (1952). (The Cahformia statute apparently does not apply to cases in which a different disposition would better carry out the transferor's intent. See Estate of Lefranc, supra). (5) Creditors in Cahifornia can reach any alienable interest, vested or contingent, unless the court deternines that only a nominal sum would be obtained upon creditor's sale. Anglo Cahfornia Nat'l Bank v. Kidd, 58 Cal. App. 2d 651, 137 P.2d 460 (1943). (6) California statutes give the owner of any interest in property the right to bring an action for partition or judicial sale, CAL. CODE Crv. Pro. $\S \S 752,763,781$ (West 1955); Geary v. de Espmosa, 51 Cal. App. 52, 196 P. 90 (1921), and such partition or sale can be secured against the holder of either a vested or contingent future interest. CaL. Code Crv. Pro. \$ 766 (West 1955); Garside v. Garside, 80 Cal. App. 2d 318, 181 P.2d 655 (1947).

The question of whether the taker of a future interest must survive the life tenant or survive to the date of distribution is often awkwardly rephrased as a question of whether the interest is contingent or vested. Contingent means only that survivorship is required; vested means that it is not. It is obvious that Civil Code $\S 715.8$ can have no application to survivorship problems.

5 But see Comment, California Revises the Rule Against Perpetuities-Again, 16 Stav. L. REv. 177 (1963). From 1872 to 1959 the rule against suspension of the power of alienation was in effect in California. CAI. CIV. CoDE $\$ \S 715,715.1$ (the forner was repealed in 1951, 
Case 1. $O$ conveys Blackacre to $A$ (a bachelor) for life, then to $A$ 's children for their lives, then to $A$ 's grandchildren in fee simple. The remainder to $A$ 's grandchildren, if valid, might suspend the power of alienation during the lives of $A$ 's children, all of whom are unborn. Under the old rule prohibiting suspension of the power of alienation this remainder, and only this remainder, is void. The life estate in $A$ and the secondary life estate in $A$ 's children are valid since they suspend the power of ahenation only during the life of $A$, a person in being.

Case 2. Assume the same conveyance as in Case 1. No interest is presently vested under Civil Code section 715.8 since a fee simple title to Blackacre cannot now be conveyed. No interest will necessarily vest until after the death of $A$ 's children, for only at that time will all the remaindermen be ascertained. Since $A$ is a bachelor and any child he may leave surviving him is now unborn, all the interests might vest too remotely under Civil Code section 715.8. Under section 715.8 all interests are vested if fee simple title to the property can be conveyed. This is an all-or-none approach, which differs from the selective invalidation of interests by the old rule against suspension of the power of ahenation.

The fact that an interest might, under Civil Code section 715.8, remain unvested beyond lives in being plus twenty-one years does not mean that the interest is void. The life estate in $A$ and the secondary life estate in $A$ 's children in Case 1 may remain unvested under this section during the lives of $A$ 's unborn children, but both life estates are valid. This result follows from section 8 of the enacting statute, which provided: "This act does not invalidate, or modify the terms of, any interest which would have been valid prior to its enactment, and any sucli interest which would have been valid prior to its effective date is valid irrespective of the provisions of this act." This result also arguably follows from the fact that Civil Code section 715.8 does not expressly provide that the definition of vesting therein shall be the only meaning of vested under the Rule.

In summary, Civil Code section 715.8 provides an alternative definition of vesting. An interest in property is valid if (a) the interest must vest (using the common law meaning of vest), if at all, within lives in being plus twenty-one years, or (b) it is certain that a fee simple title to the property can be conveyed within lives in being plus twenty-one years.

ch. 1463, § 7, [1951] Cal. Stats. 3443; the latter was repealed in 1959, ch. 470, §1, [1959] Cal. Stats. 2405. The common law Rule Against Perpetuities (the rule against reinote vesting) was adopted in 1951. CAL. Crv. Code § 715.2 (West 1954).

6 Ch. 1455, § 8, [1963] Cal. Stats. 3010. 
II

TRANSACTIONS EXEMPTED FROM THE RULE

\section{A. Commercial Transactions}

The alternative meaning of "vested" in Civil Code section 715.8 will have an impact primarily on three kinds of dispositions. The first is commercial transactions. Where there are instruments creating leasehold interests, easements, options to purchase, and mineral interests, there ordinarily will be persons in being who, by conveying all the separate interests, can convey a fee simple. The Rule Against Perpetuities thus will have hittle application to commercial transactions. As a matter of policy few people will quarrel with this result. The application of the Rule to commercial transactions has long been under attack. ${ }^{\top}$

\section{B. Forfeiture Land-Use Restrictions}

The second area where Civil Code section 715.8 will have an impact concerns forfeiture restrictions upon the use of land. A forfeiture interest created in the grantor or in the testator's heirs is a possibility of reverter or right of entry, exempt from the Rule. Where the forfeiture interest is created in a transferee, it is an executory interest subject to the Rule. A forfeiture interest that is an executory interest will rarely violate the Rule in view of Civil Code section 715.8 inasmuch as the holder of the fee simple and the holder of the executory interest can convey an absolute fee simple. Thus:

Case 3. $O$ conveys Blackacre to Trinity Church so long as used for church purposes, then to $A$ and his heirs. Trinity Church and $A$ can convey a fee simple absolute. A's executory interest is vested by Civil Code section 715.8.

For treating alike these functional equivalents (possibilities of reverter, rights of entry, and executory interests to enforce land use restrictions), the alternative definition of vesting deserves applause. Many scholars will sit on their hands, however, inasmuch as the statute, by validating executory interests, may increase the amount of land subject to forfeiture restrictions and thereby the amount of unmarketable land. This result is improbable. Unaided by statute, the courts in California have subjected possibilities of reverter and rights of entry to equitable

7 See Wong v. Di Grazia, 60 Cal. 2d 525, 386 P.2d 817, 35 Cal. Rptr. 241 (1963); 6 amertcan LaW of Property § 24.56 (1952); J. Morris and W. B. Leach, The Rule agansst Perpetuities 219-231 (2d ed. 1962); H. Whtutams and C. Meyers, 2 OII and Gas LAw $\S 325$ (1959); Berg, Long-Term Options and the Rule Against Perpetuities, 37 Calif. L. Rev. 1, 235 (1949). 
defenses that can be interposed against the enforcement of a covenant. ${ }^{8}$ It seems likely that these defenses against enforcement of land use restrictions will be extended against the functionally equivalent executory interest, now that it is free of the Rule Against Perpetuities. If the courts do extend these defenses, then the operation of the alternative definition of "vesting" in the area of land use restrictions will not be seriously objectionable.

\section{Trusts}

The third kind of property arrangement that will be affected by Civil Code section 715.8 is the private trust. Inevitably, some adventurous draftsmen will attempt to use this section to create a perpetual family trust. The statute says an interest in property is vested if one or more persons can "convey" a fee simple title to the property. There are three interpretations of the word "convey" which the courts miglit adopt. First, "convey" might be held to mean "sell." Under this interpretation, if the trustee is given the power to convey the fee simple title (or, in the case of personalty, absolute ownership) to any asset of the trust, then all interests in the trust property, legal and equitable, are vested under Civil Code section 715.8. ${ }^{9}$ If this power is given to successor trustees, then the trust is effectively exempted from the Rule Against Perpetuities. ${ }^{10}$

8 See Atkins v. Anderson, 139 Cal. App. 2d 918, 294 P.2d 727 (1956) (refusing to decree forfeiture where no damage shown); Savanna School District v. McLeod, 137 Cal. App. 2d 491, 290 P.2d 593 (1955) (applying substantial performance doctrine); Townsend v. Allen, 114 Cal. App. 2d 291, 250 P.2d 292 (1952) (applying change of circumstances doctrine); Alexander v. Title Ins. \& Trust Co., 48 Cal. App. 2d 488, 119 P.2d 992 (1941) (applying doctrine of no substantial benefit); Wedum-Aldahl Co. v. Miller, 18 Cal. App. 2d 745, 64 P.2d 762 (1937) (applying waiver).

9 Where the trust instrument does not expressly permit or forbid the trustee to sell trust property, the trustee can sell such property if it is necessary or appropriate to enable him to carry out the purposes of the trust. Church v. Church, 40 Cal. App. 2d 696, 105 P.2d 640 (1940); 2 A. ScoTr, Trusts $\$ 190$ (2d ed. 1956). It may be contended that such an imphied power of sale satisfies the requirement of Civil Code $\$$ 715.8. If it does, then a Cahfornia trust is exempt from the Rule Against Perpetuities unless the trustee is forbidden to scll the trust property.

In Wisconsin, if the trustee is given the power of sale, the trust is exempt from the Rule Against Perpetuities. Will of Walker, 258 Wis. 65, 45 N.W.2d 94 (1950). In Idaho too, perpetual private trusts of personal property are apparently permitted. IDAHо CODE $₹ 55-111$ (1957).

${ }^{10}$ Article $20, \S 9$, of the California constitution provides: "No perpetuities shall be allowed except for eleemosynary purposes." I assume this merely states a pohicy and does not incorporate into the constitution the common law Rule Against Perpetuities with all of its Byzantine complexities. Referring to similar constitutional provisions in other states, Gray said: "These provisions seem to be simply pieces of declamation without juristic value, at least on any question of remoteness." J. Gray, The RULE AGAINST PERPETUITIEs $\S 730$ (4th ed. R. Gray 1942). The issue is not settled, however. There are dicta in California cases to the effect that the constitution does enact the common law Rule. There are also dicta to the contrary. See Comment, supra note 3, at 292-295. 
The courts, moved by a different idea of what the policy against perpetuities requires, ${ }^{11}$ however, might construe the word "convey" in one of two other ways. Nevertheless, under either of these constructions, a perpetual trust is still possible.

Civil Code section 715.8 could be held to require that one or more persons have the power to convey a fee simple without consideration, i.e., the power to give property away. If this construction is given the statute, the trustee can be given the power to convey all or part of the trust property in fee simple to the income beneficiaries. Such a power would exempt the trust from the rule.

Second, a court might hold that Civil Code section 715.8 is not satisfied unless one or more persons have the power to convey a fee simple to anyone without consideration to anyone. If the statute is thus construed, the draftsman who seeks to create a perpetual trust can provide such a power in the trust instrument. He can even create such a power without its being treated as a general power of appointment for federal income, estate and gift tax purposes. Thus:

Case 4. $T$ bequeaths a fund to the Security Trust Company, in trust, to pay the income to his issue per stirpes from time to time living. Whenever there is no issue of $T$ alive, the Security Trust Company is directed to convey the trust property to The Regents of the University of California. The trustee is given the power to sell the trust property. $T$ gives the adult income beneficiaries, ${ }^{12}$ acting jointly, the power to appoint the trust property to whomsoever they see fit, but the power can be exercised only with the consent of the Regents.

The power given the beneficiaries in this example satisfies the narrowest construction of Civil Code section 715.8, as a power to give the property to anyone the donees choose. However, it is not a general power of appointment under the Internal Revenue Code because it is exercisable only with the concurrence of the Regents, who have a substantial adverse interest in the trust property. ${ }^{13}$

11 Dean Halbach, supra note 1, at $\$ 15.6$, says: "While a literal reading of [California Civil Code \$715.8] suggests an immunity for the typical trust in which the trustee bas a power of sale, this interpretation of the statute appears quite clearly to violate Article XX, $\S 9$ of the California Constitution, prohibiting perpetuities for private purposes. . . . Consequently, it is likely that a fiduciary power to sell specific trust assets will not satisfy this section. At least the draftsman, to be safe, must assune that it will not and that the section requires that the trust terminate or be terminable by the beneficiaries not later than lives in being and 21 years."

12 The interests in the trust property would become unvested if there were no adult beneficiaries, and the Rule Against Perpetuities would begin to operate again. The draftsnian can take care of this possibility by a clause which either (a) makes certain the interests will vest again within 21 years thereafter or (b) terminates the trust in this event and provides for disposition of the trust property.

13 Treas. Reg. § 20.2041-3(c)(2) (1958) (estate tax); Treas. Reg. § 25.2514-3(b) (2) 
Under orthodox perpetuities doctrine, if one person has sole and exclusive power, presently exercisable, to appoint property to himself or to anyone he pleases, the property is not considered tied up. The donee of the power is treated, for perpetuities purposes, just as if he owned the property in fee simple. The validity of any interest created by the exercise of such power, or of any interest in default of exercise, is judged from the date of exercise or from the date of termination of the power. ${ }^{14}$ If Civil Code section 715.8 is construed to require that one or more persons have the power to appoint the fee simple to anyone, including themselves, the only difference between orthodox perpetuities doctrine and section 715.8 is this: Orthodox doctrine is satisfied if one, and only one, person has the power; Civil Code section 715.8 is satisfied if one or more persons have the power..$^{15}$

(1958) (gift tax). Section 678 of the Internal Revenue Code of 1954, which treats the sole donee of an inter vivos general power as owner for income tax purposes, is inapplicable because the power is lodged in more than one person. However, althouglt the power is not a general power of appointment, and the donees are not. taxable by its mere existence, care must be taken, if the power is exercised, to avoid the possible application of $\S 2041$ (a) (3). If the power is exercised by creating a further power, undesirable tax consequences may follow. See note 15 infra.

146 AMatrican LaW of Property \$ 24.31 (1952).

15 Where the trustee or the beneficiaries have a power to convey the trust property that satisfies Civil Code $\$ 715.8$, the federal tax consequences may, in one instance, be undesirable. Section 2041(a) (3) of the Internal Revenue Code of 1954 may require the inclusion of the value of the trust property in the gross estate of the donee of a power of appointment if the donee (a) has a special power of appointment over the property and (b) exercises the power by creating a further power of appointment.

Section 2041(a) (3), applicable in all states, was enacted because of a peculiarity in the perpetuities law of Delaware. In Delaware, contrary to the law elsewhere, the interests created by the exercise of a special power of appointment are judged under the Rule Against Perpetuities from the date of exercise, not from the date of creation of the power. The appointment is not read back into the instrument creating the power. Dex. CoDE ANN. tit. $25 \$ 501$ (1953). By creating a life estate plus a special power of appointment, which is exercised by creating another life estate plus a special power of appointment, which is exercised in the same way in each succeeding generation, a trust continuing forever is possible in Delaware.

Thus: $A$ bequeaths a fund in trust to pay the income to $B$ for life, remainder to $B$ 's issue in such shares as $B$ shall appoint, and in default of appointment to $B$ 's issue per stirpes then living. At $A$ 's death $B$ is childless. By will $B$ appoints to his son $C$ for hife, remainder to $C$ 's issue in such shares as $C$ shall appoint, and in default of appointment to $C$ 's issue per stirpes then living. $C$ was not in being at $A$ 's death. By will $C$ appoints to bis son $D$ for life, remainder to $D$ 's issue in such shares as $D$ shall appoint, and in default of appointunent to $D$ 's issue per stirpes then living. These successive appointments are valid under Delaware law. In other states the remainder to $C$ 's issue, the special power of appointment in $C$, and the interests created by $C$ 's exercise of the power all violnte the Rule and are void.

Such a Delaware trust would escape federal estate taxation at the death of the donees of the special powers were it not for $\$ 2041$ (a) (3). That section includes in the gross estate of the donee the value of property subject to a special power if the power is exercised by creating a further special power which under local perpetuities law can be validly exercised so as "to postpone the vesting" of any interest in the property for a period ascertainable without regard to the date of the creation of the first power. The word "vesting" in $\$ 2041$ (a) (3) 


\section{III}

CIVIL CODE SECTION 771:

THE NEW BULWARK AGAINST PERPETUAL TRUSTS

\section{A. Termination by the Beneficiaries Permitted}

Inasmuch as under Civil Code section 715.8 private trusts may be valid for an indefinite time, Civil Code section 771 claims new importance. Section 771 provides, in part:

A trust is not invalid, either in whole or in part, merely because the duration of the trust may exceed the time within which future interests in property must vest under this title, if the interest of all the beneficiaries must vest, if at all, within such time. . . .

Whenever a trust has existed longer than the time within which future interests in property must vest under this title

(1) It shall be terminated upon the request of a majority of the beneficiaries;

(2) It may be terminated by a court of competent jurisdiction upon the petition of the Attorney General or of any person who would be affected thereby if the court finds that such termination would be in the public interest or in the best interest of a majority of persons who would be affected thereby.

Although Civil Code section 715.8 permits a trust unlimited in duration if the trust property can be conveyed, Civil Code section 771 provides that the trust may be terminated twenty-one years after some life in being at the creation of the trust. It seems clear that Civil Code section 771 has now become the principal bulwark against private perpetual trusts.

It is possible to argue that no trust in California can now violate the Rule Against Perpetuities, even a trust that does not permit the trust property to be conveyed. Since under Civil Code section 771 a trust can be terminated after it "has existed longer than" lives in being plus twenty-one years, it may be contended that the interests will necessarily vest under Civil Code section 715.8 simultaneously with the expiration

should be taken to refer to the common law meaning of "vesting in interest" or "vesting in possession."

California Civil Code $\$ 715.8$ permits the postponement of "vesting in interest" or "vesting in possession" for a period ascertainable without regard to the date of creation of the first power. Now that all special powers of appointment are exempt from the Rule Against Perpetuities in Califorma if the trustee or beneficiaries have a power to convey the trust property, \$ 2041 (a) (3) may have a broader impact on Cahfornia trusts. Before Civil Code $\S 715.8$ was enacted, $\S 2041$ (a) (3) applied to Cahfornia trusts only if the special power was exercised hy creating a general power to appoint by deed or will. Now, if the trust property ean be conveyed, $\S 2041$ (a) (3) may require the inclusion of the value of the trust property in the donee's gross estate if the donee exercises a special power by creating any power of appointunent. 
of the perpetuity period. A close reading of the statute, however, supports the contrary position that termination under Civil Code section 771 can take place only after the period has run. Thus there will be at least one moment of time between the termination of the perpetuity period and the vesting of the interests by the joint action of Civil Code sections 771 and 715.8, and that is one moment of time too much.

Civil Code section 771 provides a mare's-nest of constructional problems. The underlying principle of the statute is similar to that of the wait-and-see statutes enacted in several states. ${ }^{16}$ And, like some of these statutes, Civil Code section 771 does not specify who are the measuring lives. As a general rule, the measuring lives ought to be the beneficiaries of the trust living at the date of the creation of the trust, if "beneficiaries" can be defined under the particular trust instrument. If the statute is not so construed, Professor Robert Lynn's recent analysis of who are the measuring lives under the wait-and-see doctrine ${ }^{17}$ is relevant to the determination of measuring lives under Civil Code section 771 .

Other, and far more perplexing, constructional problems come to mind. Who are "beneficiaries"? How is the "majority" ascertained? Consider the following case:

Case 5. $T$ bequeaths a fund to the Security Trust Company, in trust, to pay the income to $T$ 's issue from time to time living per stirpes. Whenever there is no issue of $T$ alive, the Security Trust Company is directed to convey the trust property to The Regents of the University of California.

Is the University of California a "beneficiary"? If the income beneficiaries want the trust terminated and the University of California does not, how is the "majority" ascertained? Is the "majority" of income beneficiaries ascertained by reference to the number of income beneficiaries or to the size of the income shares? How is "majority" ascertained if, mstead of mandatory income provisions, discretionary provisions permit the trustee to accumulate income and distribute income and principal among a class composed of the testator's issue? Could "beneficiaries" mean the persons to whom the trust property would be distributed upon termination of the trust?

${ }^{16}$ E.g., Pa. Stat. AnN. tit. $20 § 301.4$ (b) (1950). Under the orthodox Rule Against Perpetuities an interest is void $a b$ initio if there is any possibility that the interest might vest beyond the perpetuity period. Under the wait-and-see doctrine one waits to see whether a contingent interest does in fact vest or fail within lives in being plus 21 years. If it does not, it is void. See R. Lynn, The Modern Rule Agansst Perpetuttirs 34, 47-50 (1966). Under California Civil Code $\S 771$ one waits to see whether a trust does in fact exist longer than lives in being plus 21 years. If it does, it is terninable by the beneficiaries or other interested parties.

${ }^{17} \mathrm{R}$. LYNN, supra note 16 , at 36-39, 47-50, 70-80. 
To whom is the trust property distributed upon termination of the trust? Civil Code section 771 says merely that the trust shal be terminated upon request of a majority of the beneficiaries. It does not state what disposition is to be made of the trust property. In Case 5, would the equitable hife estates in $T$ 's issue turn into legal hife estates? Could any issue born after termination of the trust share in the income? Would permitting them to share violate the Rule Against Perpetuities, as modified by Civil Code section 715.8? Or, upon termination of the trust, would the trust property be held on a resulting trust for T's heirs? In this event would the estates of $T$ 's heirs and the subsequent estates through which the reversionary interests passed have to be reopened and administrators appointed and death taxes paid? Civil Code section 771 is silent on all these problems.

\section{B. Federal Tax Consequences of Civil Code Section 771}

The federal tax consequences of a power to terminate held by a majority of the beneficiaries of a trust cannot be known definitely until the constructional questions raised above are answered and, of course, until the exact terms of the trust instrument are known. ${ }^{18}$ However, it is now possible to create in California a private trust that will avoid federal estate and gift taxes for many generations, potentially forever. This is possible if (a) the power to terminate the trust under Civil Code section 771 is not a general power of appointment for tax purposes because held with an adverse party, or (b) the power to terminate is renounced by the beneficiaries of the trust.

The persons who liave the power to terminate a trust have a power of appointment. ${ }^{19}$ If this power is a general power of appointment, as defined by the Internal Revenue Code, ${ }^{20}$ the persons holding the power are treated as owners of the trust property. To decide whether the power to terminate a trust under Civil Code section 771 is a general power of appointment, ${ }^{21}$ we must first know (a) who has the power and (b) who will take the trust corpus on termination of the trust. If the persons who have the power to terminate would receive the trust property upon termination, such persons have a general power of appointment for purposes of federal estate and gift taxes, unless the power is held with

18 I am indebted to my colleagues Ralph Rice, Herbert Schwartz and Alan Liker who explored the tax problems with me. Only a few of the many tax problems that might arise from the application of Civil Code $\S 771$ to particular trust instruments are considered here.

19 Treas. Reg. § 20.2041-1(b) (1) (1958).

20 INT. Rev. CODE of 1954, § 2041(b) (1).

21 Since the power to terminate cannot be exercised until the perpetuity period has run, the power is not a general power of appointanent in the estate of any beneficiary. who dies before the perpetuity period has run. Treas. Reg. $\S 20.2041-3$ (b) (1958). 
an adverse party. ${ }^{22}$ If the principal would be distributed to persons other than those who have the power to terminate, the power to terminate is a special power of appointment. The persons who hold a special power are not treated as owners of the trust property by the federal estate and gift tax laws.

To illustrate a situation where Civil Code section 771 would not give the beneficiaries of the trust a general power of appointment because held with an adverse party, consider the following trust instrument, which creates a trust exempt from the Rule Against Perpetuities in California.

Case 6. $T$ bequeaths a fund to the Security Trust Company, in trust, with discretion to accumulate income or to distribute part or all of the income or principal among T's issue and spouses of issue, from time to time living in such shares as the trustee in its sole discretion determines. Whenever there is no issue or spouse of issue of $T$ alive, the Security Trust Company is directed to convey the trust property to The Regents of the University of California. To vest all the interests in the trust under Civil Code section 715.8, the trustee is given the power to convey the trust property (or, if a more restricted view of section 715.8 is taken, the testator's adult issue and adult spouses of issue, with the consent of the Regents, are given the power to appoint the trust property to whomever they please)..$^{23}$ At the expiration of the perpetuity period, three greatgrandchildren of $T$ are alive. They are $X, Y$, and $Z$.

If, under Civil Code section 771, $X, Y$, and $Z$ have the power to terminate and each receives one-third of the trust property upon termination, then each has a general power of appointment over one-third of the property unless each holds the power with an adverse party. The position that the power is held with an adverse party seems sound. The estate tax regulations provide:

[A] cololder of a power is considered as having an adverse interest where lie may possess the power after the decedent's death and may exercise it at that time in favor of himself, his estate, his creditors, or the creditors of his estate. Thus, for example, if $X, Y$, and $Z$ held a power jointly to appoint among a group of persons which includes themselves and if on the death of $X$ the power will pass to $Y$ and $Z$ jointly, then $Y$ and $Z$ are considered to have interests adverse to the exercise of the power in favor of $X$. Similarly, if on $Y$ 's death the power will pass to $Z, Z$ is considered to have an interest adverse to the exercise of the power in favor of $Y^{24}$

22 INT. REv. Code of 1954, \$§ 2041(b)(1)(C) (iii), 2514(c) (3)(C).

${ }^{23} \mathrm{~A}$ power in the life tenants to convey, with the consent of the remainderman, is not a general power of appointment for tax purposes. See note 13 supra.

24 Tréas. Reg. § 20.2041-3(c)(2) (1958). Sée also Treas. Reg. § 25.2514-3(b)(2) (1958) (gift $\operatorname{tax}$ ). 
Civil Code section 771 does not provide what happens to the power to terminate when one of the beneficiaries dies. The most reasonable construction of the statute is that the power to terminate is exercisable by the majority of the beneficiaries from time to time living. To hold that the beneficiaries having the power are ascertained at the expiration of the perpetuity period and that such power cannot be exercised by successor beneficiaries would mean that the trust could never be terminated by request of the beneficiaries after the death of the original holders of the power. Such an interpretation would defeat the purpose of the statute which is to make trusts terminable. If the power to terminate is exercisable by a majority of the successor beneficiaries from time to time living, then in Case 6 the power is held with adverse parties. If $X$ dies, for example, his beneficial interest ends, and the surviving beneficiaries can terminate the trust and receive the trust property. The estate tax regulation quoted above appears to apply.

It may be contended, in addition, that the power held by $X, Y$, and $Z$ is held with adverse parties because there is an income tax advantage to some of the donees in not terminating the trust. If the trust is not terminated, the trustee can apportion the income among the three in such a manner as to reduce the total income taxation. ${ }^{25}$ Thus, the income tax advantage of the trust continues even though the trust can be terminated. ${ }^{26}$ Because of this, it is possible for the beneficiaries to argue that the power to terminate is not a general power of appointment since the power is exercisable only in conjunction with a person having a substantial adverse interest, that is, with the other beneficiaries wlo might have to pay more income tax if the trust were terminated. ${ }^{27}$ However, it is doubtful that this argument would succeed, since the Commissioner has taken the position that an adverse interest means an adverse property interest. ${ }^{28}$

I have assumed in Case 6 that the University of California will not

${ }^{25}$ Section 678 of the Internal Revenue Code of 1954, which treats the donee as owner for income tax purposes, is inapplicable to the power to terminate because the power is not exercisable solely by one person for his own benefit. Nor would a gift tax usually be payable if the trustee distributes all the income to one of the three donees. True, the power to terminate to that extent may lapse. And a lapse is a gift. But even if the power is treated as a general power, the other two donees have not made taxable gifts to the one income recipient unless the amount paid out exceeds $\$ 5,000$ or $5 \%$ of the value of the corpus per beneficiary. INT. REv. CODE of 1954, § 2514(e).

26 For other possible income tax advantages from continuing the trust, see Somers, Some Income Tax Problems Incident to the Ternination of a Trust, 14 TAx L. REv. 85 (1958).

27 INT. Rev. CoDE of 1954, $\S \S 2041$ (b) (1) (C) (ii), 2514 (c) (3) (B).

28 Treas. Reg. § 20.2041-3(c)(2) (1958); Commissioner v. Prouty, 115 F.2d 331 (1st Cir. 1940). 
be entitled to distribution of any part of the trust property since the condition precedent-death of all testator's issue and spouses of issuehas not happened. If the University of California were held to be a coholder of the power of termination or if it were given some share of the property upon termination of the trust, the conclusion above that the power is not a general power of appointment because held with an adverse party would not be changed.

If there is, in any case, a substantial possibility that the power to terminate the trust under Civil Code section 771 will be treated as a general power of appointment, the beneficiaries can renounce the power within a reasonable period of time after it becomes exercisable by them. A renunciation effective under local law is not a taxable gift ${ }^{20}$ and, of course, there would be no estate tax payable at the death of the beneficiaries who renounce. ${ }^{30}$ California Civil Code section 1060 provides that any power can be released or converted into a special power. There is no reason to believe that the power to terminate given by Civil Code section 771 is not releasable. The purpose of section 771 is to make it possible to terminate trusts, and that purpose can still be carried out in a suit to terminate the trust brought by the Attorney General or any one beneficiary or other interested party.

If the above analysis of Civil Code section 771 and the pertinent provisions of the Internal Revenue Code is correct, a trust can be created in California that will avoid estate and gift taxation for lives in being plus twenty-one years and for so long thereafter as the trust is not terminated by the beneficiaries or upon suit by the Attorney General or some other interested party. ${ }^{31}$ Widespread use of such trusts would surely stir Congress into action, either to change the basic tax law or to confer tax benefits upon transfers that comply with a federal rule against perpetuities.

IV

IS EXEMPTION OF TRUSTS FROM THE RULE AGAINST PERPETUITIES IN ACCORD WITH SOUND POLICX?

Underlying the Rule Against Perpetuities are two basic policies: (1) making alienable and marketable specific assets, such as land, stocks,

20 Treas. Reg. \& 25.2514-3(c)(5) (1958). Hardenbergh v. Commissioner, 198 F.2d 63 (8th Cir. 1952), cert. denied, 344 U.S. 836 (1952), does not seem to apply here. "Title" does not pass by operation of CAL. CIv. CoDE $\$ 771$. Moreover, the power to terminate created by $\S 771$ is not an absolute power in each beneficiary. Each individual beneficiary must act with enough others to constitute a majority. Such a power is clearly different from the absolute title that passes by intestacy.

30 Treas. Reg. $\S 20.2041-3$ (d)(6) (1958).

31 Such a trust would be inflexible and madvisable unless special powers of appointment were given to the beneficiaries. If these powers were exercisd by creating a further power, the value of the property subject to the power might be included in the donee's gross estate. See note 15 supra. 
and bonds; and (2) preventing the tying up of a quantum of wealth in trust for an undue length of time. The first policy is satisfied if the trustee of a trust is given the power to sell the trust property and reinvest the proceeds. As the trustee almost always has the power of sale, we are not here concerned with that policy.

The policy against tying up a quantum of wealth in trust seeks at least three objectives. First are the benefits from a turn-over of wealth. A trust locks wealth out of certain areas of the market. The trustee cannot spend the trust property for consumer goods, for travel, or for personal services. Nor can the trustee normally invest in higli-risk enterprises. Perpetuities policy is grounded upon the notion that society will profit poth economically and socially if persons are free to spend their wealth, including their capital, in any way they choose. This policy has an obvious connection with Adam Smith and market economics.

Second, by terminating a trust and turning the trust property over to the beneficiaries to manage, the managerial competence of the beneficiaries will be tested. The incompetent will be purged from the wealthy class, and society will be better off. In a welfare state, this objective is of less importance than it used to be.

Third, and perhaps most important, is the objective of eliminating dead-hand control. An ancient policy of the law is the policy in favor of the living being masters of their own fate. It springs from a deep psychological need of every person to control his environment - to be his own boss. Professor Lewis Simes has written, "[T] he Rule against Perpetuities strikes a fair balance between the desires of members of the present generation, and similar desires of succeeding generations, to do what they wish with the property which they enjoy."32

Are these policies satisfied if a trust may be terminated after the perpetuity period has run? Under California law there is no certainty that the trust will be then terminated. The majority of beneficiaries may elect to terminate or the court may order termination upon suit by the Attorney General or by "any person who would be affected thereby." It is arguable that the policy against perpetuities is not satisfied unless we are certain that the trust will be terminated. The beneficiaries may not want the trust terminated, since the trust corpus may be immune from the claims of creditors, spouses or taxing authorities. ${ }^{33}$ If the benefi-

32 L. Stares, Public Policy and the Dead Hand 58 (1955).

33 One or more of the beneficiaries may also wish to qualify for some type of governmental assistance which is availahle only to persons with insufficient resources of their own. Will the trust property be considered the property of a beneficiary in determining whether the beneficiary qualifies for public assistance? Consider, for example, the recently enacted medical assistance programs. The federal statutes, which authorize grants to the states for medical assistance programs, generally leave to the states the definition of medically indigent persons. E.g., 42 U.S.C. $\S \S 302(\mathrm{a})(10), 602$ (a) (7), 1382(a)(14) (1964); id. § 1396 (Supp. I 1966). 
ciaries would lose income, estate and gift tax advantages by terminating the trust, or if the property would then be subject to creditors or to alimony claims, the beneficiaries are not completely free "to do what they wish with the property they enjoy." The costs of termination may substantially inlibit the beneficiaries from doing what they wisl.

On the other land, the public interest in liaving the trust terminated may be realized by the affirmative action of the Attorney General or of "any person who would be affected thereby." The Attorney General's power to bring suit may satisfy the policies against perpetuities. However, the Attorney General presently keeps no records of private trusts. A complete list of sucli trusts would be hard to produce inasmuch as inter vivos transfers in trust are not recorded in any public records unless real property is involved. A statute could be enacted requiring trusts to be recorded with the Attorney General's office, but the enforcement of sucl a statute would require ingenious measures. Although tax returns of private trusts are kept by the Internal Revenue Service, the Service could not disclose information therein to the state Attorney General without an executive order. ${ }^{34}$

One of the virtues of the old Rule Against Perpetuities was that public policy was enforced by private action. If a person contended successfully that another's interest in property violated the Rule, the cliallenger-a private individual-was usually rewarded by receiving an interest in the property limself. This incentive to private enforcement was deemed sufficient insurance that perpetuities policy would be enforced. Public enforcement by the Attorney General miglit be more expensive and less effective.

It is important to note that Civil Code section 771 provides for termination of a trust by a court upon petition of "any person who would be affected thereby." This provision miglit cure the objection that the beneficiaries are not substantially free to terminate the trust because of the

The California Welfare and Institutions Code contains vague "property" qualifications for public assistance. One section denies public assistance to an apphicant unless "the property he owns" is of a specified exempt kind or is valued below a specified amount. CAL. WELF. \& Irst'Ns Cone § 11151 (West 1966) (enphasis added). The California Medi-Cal program, id. $\$ \S 14000-157,14500-653$, provides basic health eare and extended health services to recipients of public assistance and to medically indigent persons whose average monthly inconie is not sufficient to provide for "the cost of health care or coverage less any amount by which the value of his other resources, oroned by him alone or in combination with his spouse exceeds" a specified value. id. $\S 14005$ (emphasis added). It is far from clear that 'owned property' includes property in a discretionary trust of which the applicant is a possible income beneficiary and over which the applicant has a power of appointment exercisable with a majority of beneficiaries or with consent of a court.

34 INT. REv. CoDE of $1954, \S 6103$. Penalties are provided for unauthorized disclosure. $I d$. $\S$ 7213. CAL. REv. \& TAX CODE $\S \S 19282,19285$ (West 1956) contain similar provisions for secrecy. 
cost involved. The cost is that the property, freed of trust, is subject to claims of creditors, spouses and tax authorities. If creditors, spouses and tax authorities are "persons who would be affected" by the termination of the trust and may petition for termination, the only policy objection to the contimuation of the trust is that a lawsuit is required to terminate the trust. The costs of a lawsuit may inhibit the action of the persons affected. It is important also to note that the effect of this provision in section 771 may be to extend the enforcement of perpetuities policy to the Commissioner of Internal Revenue. When he is aware that a trust has existed longer than lives in being plus twenty-one years, perliaps lie may sue to terminate the trust so that the property becomes subject to estate and gift taxes once again. Proper enforcement by the Commissioner would require that he keep records of "measuring lives" of California trusts. This in turn would require the Commissioner to become an expert in the wait-and-see doctrine, which is applicable to the termination of trusts under section 771.

If some means could be devised to make certain that trusts would terminate and that the corpus would be distributed in fee simple twentyone years after some life in being, there miglit be no reason for applying the Rule Against Perpetuities to private trusts. Perpetuities policy may require certainty, not simply a possibility, that private trusts will be terminated within or at the end of the perpetuity period. This appears to be recognized by those judges who, in Professor Lynn's plirase, "grope for a 'possessory' test"35 for vesting under the Rule Against Perpetuities.

If the policy against perpetuities is not satisfied by the possibility that a trust will be terminated after lives in being plus twenty-one years by the beneficiaries, the Attorney General or some other interested party, Civil Code section 715.8, as applied to trusts, may violate the state constitutional proluibition of "perpetuities."

35 R. LyNN, supra note 16, at 31 . In a study of Kentucky cases a few years ago, I came to the conclusion that the Kentucky court was seriously disturbed by trusts unlimited in duration and had effectively limited their duration by invalidating trusts where the fee simple would not vest in possession free of any trust at the end of the perpetuity period. J. Dukemittier, Perpetutties Law IN Action 19-30, 57-65 (1962). See also Burton v. Hicks, 220 Ga. 29, I36 S.E.2d 759 (1964), holding a trust for 25 years void, even though all interest in the trust would vest within lives in being.

36 See notes 10-11 supra. Any draftsman who is concerned about the constitutional problem or about the construction of Civil Code $\$ 715.8$ can include a savings clause providing as follows: "The trust shall terminate twenty-one years after the death of the survivor of specific named persons [naming all presently living persons who are possible beneficiaries], unless within that period it has been determined by a court of competent jurisdiction that the trust may lawfully continue until terminated under Civil Code section 771, in which case the trust shall continue until it is terminated under Civil Code section 771." 
POSTSCRIPT

The Committee on Rules Against Perpetuities of the American Bar Association Section of Real Property, Probate and Trust Law, has this summer published a new edition of the Perpetuity Legislation Hand$b o o k .{ }^{37}$ This handbook contains a collection of "well-drawn legislation". Some of the statutes provide basic modifications of perpetuities doctrine, such as wait-and-see or cy pres. Other statutes embody efforts to remedy specific problems. One of the proposed statutes is a "Trust Duration Statute", ${ }^{38}$ which is under consideration by a joint committee of the Chicago and mlinois Bar Associations. The statute exempts trusts from the Rule Against Perpetuities and provides, in essence, that trusts "shall terminate at the expiration of . . 21 years after the death of all of the beneficiaries of the trust who were living" when the trust commenced. The California legislature would be well-advised to consider replacing Civil Code section 771 with the trust duration statute proposed for Illinois.

37 Perpetuity Legislation Handbook, 2 ReAL PR., PRoB. \& TruST J. 176 (1967). Professor Olin Browder of Michigan was chairman of the committee.

$38 I d$. at 202. 